\title{
Health of Nurses with Leadership and Management Functions: An Integrative Review
}

\author{
C. Gonnelli' ${ }^{1}$, R. Raffagnino ${ }^{2}$ \\ ${ }^{1}$ Local Health Unity (USL), Psychiatric Service, Siena, Italy \\ ${ }^{2}$ Department of Health Science, Florence University, Florence, Italy \\ Email: claudia.gonnelli@uslsudest.toscana.it, rosalba.raffagnino@unifi.it
}

How to cite this paper: Gonnelli, C. and Raffagnino, R. (2018) Health of Nurses with Leadership and Management Functions: An Integrative Review. Open Journal of Social Sciences, 6, 106-131. https://doi.org/10.4236/jss.2018.610010

Received: September 17, 2018

Accepted: October 23, 2018

Published: October 26, 2018

Copyright $\odot 2018$ by authors and Scientific Research Publishing Inc. This work is licensed under the Creative Commons Attribution International License (CC BY 4.0).

http://creativecommons.org/licenses/by/4.0/

(c) (i) Open Access

\begin{abstract}
The purpose of this paper is to present findings of an integrative literature review related to health and wellbeing of nurses with leadership and management functions and its associated factors, in order to provide the best available evidence on this topic. A large body of knowledge related to nursing health and well-being exists, but little we know about this topic in a nurse leadership and management role. It is a complex role in nursing that implies both clinical and leadership knowledge and abilities. A comprehensive search of electronic databases, focusing on articles published in English and Italian languages during 2009-2018, was completed. A three-step approach was used and from the original 1345 studies, 17 papers were included in this systematic literature review. Two independent reviewers analyzed these papers for critical appraisal on methodological quality and their topics. Narrative synthesis of the empirical literature allowed highlighting the most important results related to the topic investigated. This integrative review has shown that nurse leader and manager roles are stressful mainly for its specific functions and job demands. Directions for future high-quality research are suggested both to deepen the relative importance of the specific risk and protective health factors in nursing leadership roles.
\end{abstract}

\section{Keywords}

Nursing Leadership, Nursing Management, Job Health, Job Wellbeing, Job Satisfaction

\section{Introduction}

Nursing is a stressful job and nurses live many and various stressors ranging from their role to job demands, colleagues, family and patient relationships. If 
repeated, these stressors can negatively affect nurses' physical and mental health and their well-being. In literature, burnout syndrome is widely documented [1]. It is a maladaptive psychological and behavioral response to chronic emotional and interpersonal work-related stressors and it comprises emotional exhaustion or loss of emotional resources and energy, depersonalization or insensitivity, negative and cynical attitude, and lack of compassion towards fellow workers and the healthcare users, as well as loss of feeling of personal accomplishment [2]. Other than burnout, many studies observed also the presence of occupational fatigue (acute, chronic, physical and mental states) in nursing that arises due to the excessive job demands requested to such healthcare professionals [3], the psychological and physiological distress [4], depression [5], insufficient/poor-quality sleep [6] [7], and due to poor job satisfaction [8].

The associations between stressful work situations and health and well-being outcomes are varied and complex. In fact, stressful outcomes depend on different personal and job factors. For instance, certain researchers refer to the imbalance among work tasks assigned and work rewards [9], others refer to personal resources, such as emotional intelligence, emotional regulation, empathy, resilience [10] [11] [12] [13]. Beyond these personal variables, social, relational and interpersonal dimensions, such as social support and efficient leadership also seem to be protective factors of nurse health and well-being [14] [15] [16].

In the healthcare sector, nurses work in different settings, and occupy different professional roles, and thus the various stressors and job resources can have different weights and effects. While many researchers observed the job stressors specific to job settings, only few studies focused on nursing job roles.

Nurses with the functions of leadership and management are receiving growing interest among the various nursing roles. Roles such as nurse leaders or nurse managers involve both the clinical nursing competencies and specific functions related to administrative management and coordinating nursing team [15]. International research provides a broad understanding of the functions, skills, and competencies related to nursing leadership. In literature, we can observe a wide variety of nursing figures that cover such functions (clinical nurse leader, clinical nurse specialist, nurse manager, charge nurse, first-line nurse managers, ward sister, ward manager, nursing unit manager or matron), although often this wide range of professional figures is associated with a lack of clarity in its definition. Upon offering a summary of the nursing leadership denominations used in the various countries, Admi and Eilon-Moshe [17] argued that: "the same terms are used for different roles, similar roles are given different titles, and terms are frequently used interchangeably with no universal consistency or standardization" (pg. 49). However, in literature the scholars proposed certain definitions that help to identify the clinical skills and the qualities and resources of leadership and management in order to effectively carry out their tasks. Therefore, we have identified the aforementioned clinical nurse leader $(\mathrm{CNL})$, a new role that was born above all to respond to the changes of an increasingly complex and tech- 
nologically advanced health system [18]. He/she has both clinical management tasks in the health sector and implements the coordination of clinical patient care activities as a member of the nurse staff [19]. Thus, his/her main function is clinical leadership, that implies-above all-knowledge and abilities related to communication as well as intra and inter-relationships with the team and the way staff is involved in nursing activities [20]. As affirmed by Hartranft, Garcia and Adams [21], the CNL provides "direct care and clinical leadership at the bedside" (pg. 261). In the USA, one of the four established advanced practice nursing roles is the clinical nurse specialist (CNS), which includes certified registered nurse anesthetists, certified nurse-midwives, and nurse practitioners. Such nurses provide patient care, nursing education, and leadership [22]. Strictly in terms of management, a number of researchers referred to nurse managers, useful for the ward organization functioning, as having good patient care outcomes and environmental job quality [23]. They are also defined first-line nurse managers or frontline nurse managers in order to point out how they play a role as leaders and coordinators in the front line, interfacing directly with the nursing staff, physicians, patients, and their family members [24]. In certain cases, though not frequently, literature mentions charge nurses, who are the heads of a nursing unit, taking care of patients and their safety, coordinating the nurse staff, managing the multidisciplinary team, and observing the organizational policy [17].

The role of nurses with leadership and management functions has been recognized important both in terms of efficient patient care and in terms of the creation of a satisfactory and functional job setting for the professionals that work in it [25] [26]. At the same time, literature has recognized its complexity, as nurses in this role are required to have numerous and different competences, abilities, responsibilities and are expected to show an efficient intra and inter-professional collaboration [27]. Gaskin, Ockerby, Smith, Russell and O'Connell [28] found that managerial functions are mainly perceived by the workers as important challenges to be answered. On the other hand, Gantz et al. [29] - upon observing nurse leaders working in different countries such as the UK, Singapore and the USA-noticed that the workers face common global problems regarding staffing, competency development, reduced health-care funding, and maintaining quality.

A large research area focuses on leadership styles, assessing their efficiency mainly in terms of work productivity and quality [30], nursing motivation [31], and nurse staff stress and burnout prevention [32] as well as the efficiency of patient care [26]. The scholars also affirmed that there is no managing style more effective than another, and considered it is important to adapt the different styles to the specific objectives, needs, and situations each nursing leader manages [15]. They believe that, above all, behavior and attitude authenticity of the leader [33], the empowering abilities [34] are important in order to have a productive, high-quality, satisfying job environment and in order to prevent staff stress and 
burnout.

The international literature concerning nurse leaders and managers focused especially on their performance efficiency, viewing both the barriers and the opportunities to best perform their functions. These researches have been carried out in different cultural and social contexts, which may make it difficult to generalize the findings. Nevertheless, they allow having a composite picture of the risk and protective factors on effective performance. For instance, Adatara et al. [35] found that poor motivation, lack of logistics, lack of support from superiors, lack of training in management and leadership skills, poor delegation of authority from superiors, and inadequate staffing are barriers to the effective performance of nursing unit manager roles. According to Lundgrén-Laine, Kalafati, Kontio, Kauko and Salanterä [36] the charge nurses, managing daily intensive care activities, should have versatile, immediate information about the general organization and job management for a successful outcome on patient care and nurse staff.

While extensive research focused on various nurse leader and manager job competences, other equally extensive research focused specifically on their psychosocial abilities, such as emotional intelligence [37], communicative and interpersonal skills [38], resilience or the ability to adapt to adversity, using individual and organizational resources such as positive thinking, flexibility, responsibility and knowing how to separate work from personal life [39]. In terms of resilience, White, Pillay and Huang [40] recognized the important role of innovation skills, and Luo, Shen, Lou, He and Sun [41] also highlighted the role of communication and stress management.

Another research area, although not widely developed, pertains to the nurses motivations and expectations to access roles and positions of leadership and management. In certain cases, scholars refer to motivations related to productive changes in hospital departments [42], but more often they focused on fears in covering these roles, such as the fear of job failure and of struggling to balance work commitments with family tasks [42]. Doria [43] outlined not only the fear of job failure, but also inadequacy feelings for the lack of role experience, the possible envy from colleagues, especially if the nurse has been promoted leader in the same ward where he/she worked as a nurse. On the other hand, if the promotion to a new role takes place with the transfer to a different ward, nurses must nevertheless face the lack of experience and knowledge the new setting, which they must learn the culture and habits of. Furthermore, certain scholars recognized generational differences as a challenge for the nurse managers, as the latter interact with nurses who may think and behave in different ways due to their age and their disparate generational values [44]. Finally, nursing leadership has an intermediary position within the hospital hierarchy that may entail a tension between the needs and values of the two parties [45].

In recent years, research concerning stressful situations for nurse leaders and nurse managers has had an interesting development, observing mainly the role 
of certain job features, such as role overload, workloads, role ambiguity, inadequate or insufficient human resources, financial responsibilities, organizational constraints, and intrapersonal distress [46] [47] [48]. The most stressful situations seem to be specific to leadership and management functions, as Admi and Moshe-Eilon [49] affirmed. The scholars also affirmed that in nursing leadership another widely present factor is turnover intention, influenced-as Brown, Fraser, Wong, Muise and Cummings [50] sustained in their review-by various factors, such as job satisfaction, commitment, culture and value organization, and lack of time to complete tasks, leading to work/life imbalance.

Job satisfaction has also been an object of research interest, as it is considered an important criterion to assess job well-being. A report by Lee and Cummings [51] allows to observe how-among front line nurse managers-this factor is influenced by span of control, organizational support, and empowerment.

The empirical literature permits to observe as nurse leadership and management is a job position that involves not only to stressful situations similar to those of the nursing staff, but also those of leadership and management functions. Many researches and reviews have outline that these roles can be stressful and, in some, their risk and protective factors have been identified [48]. In any case, studies concerning stressful outcomes on nurse leader's health and well-being are more scarce, thus there is a gap between the broad and complex, even if sometimes confused, empirical knowledge of such topics related to nursing staff. Instead, such knowledge would be important not only to have more information about the nursing role differences, but also to improve their job efficiency and quality, as nurse leaders and managers play as essential roles in the quality of nursing staff job and the efficiency of patient care [52].

Considering that in empirical literature there are recent reviews about stress and stressful situations lived by nurses with leadership and management roles [48], the aim of our paper is to make a contribution to current international knowledge, focusing on the physical and psychological health and well-being of these nursing figures, by proposing a systematic review of the literature in order to acknowledge the state of the art on this topic. It is important not only for the development of knowledge in such area, but also to obtain useful indications about the implementation of primary, secondary, and tertiary prevention programs for the health and well-being of nursing leaders and managers.

\section{Methods}

\subsection{Aim}

The aim of this paper is to present a systematic review concerning the health and well-being as well as their risk and protection factors among nurses who took on leadership and management roles. Although there are certain emerging links between stressful situations and stress outcomes, even in a recent study [48], the specific health and well-being outcomes in such professionals are under-explored. It will be the awareness of this topic and the understanding of its current evi- 
dence by researchers and operators that will improve education and practice in the field, as well as providing the basis for future health and well-being preventive measures. Three questions guided the review: 1) What is the level of health and well-being in nurse leaders and nurse managers? 2) What are the main risks and protection factors? 3) What are the effects of health and wellbeing aspects on personal and work-related outcomes?

\subsection{Design}

A review design, involving a checklist to analyze the paper using inclusion and exclusion criteria was employed to guide the review and the rigor of the process. The review synthesis is narrative, because it allows having a full picture of the topics and the methods. Two summary sheets are employed for an easy and immediate knowledge concerning the topics, background, methods and main findings. In terms of inclusion criteria, we have choose the articles: 1) published in the 2009-2018 decade; 2) published in English and Italian language; 3) published in peer review international journals; 4) of which it has been possible to have full test results; 5) that focused on systematic reviews and empirical researches; 6) that specifically considered both nurses with leadership and management functions and that such professionals are distinct from other nursing participants; 7) that focused on physical and mental health, well-being, job satisfaction and burnout. In terms of exclusion criteria we have rejected articles: 1) having methodological limits or poor in terms of research method; 2) focusing on students who cannot have sufficient experience of the role and its outcomes in terms of health and well-being; 3) whose findings did not allow to distinguish those related to the sample of nurse leaders and managers; 4) measuring variables which are not associated with health and well-being; 5) focusing on stress and its risk and protection factors, as we found a recent review in literature on this specific topic [48].

\subsection{Search Strategy}

The search strategy involved three steps (for their synthesis, see Figure 1).

1) The first step included systematic searches in the database ScienceDirect, PubMed, PsycINFO, and Google Scholar. Search terms were: nurse leader, clinical nurse leader, charge nurse, ward sister, nurse manager, nursing leadership, nursing leadership AND healthcare, nursing health, nursing research, nursing care. In this first step, we have also included editorials $(n=9)$ and brief reports $(n=31)$, useful for a full background of the review topic. We have left out proceedings because they entail a time investment for virtually irrelevant material.

2) In a second step, based upon the information provided in the title and abstract, all studies found during the database search were assessed for their relevance to our review. We identified 1090 papers. The papers meet the inclusion criteria and a full report of the papers was retrieved.

3) In the third step, the full texts were examined independently by the two 


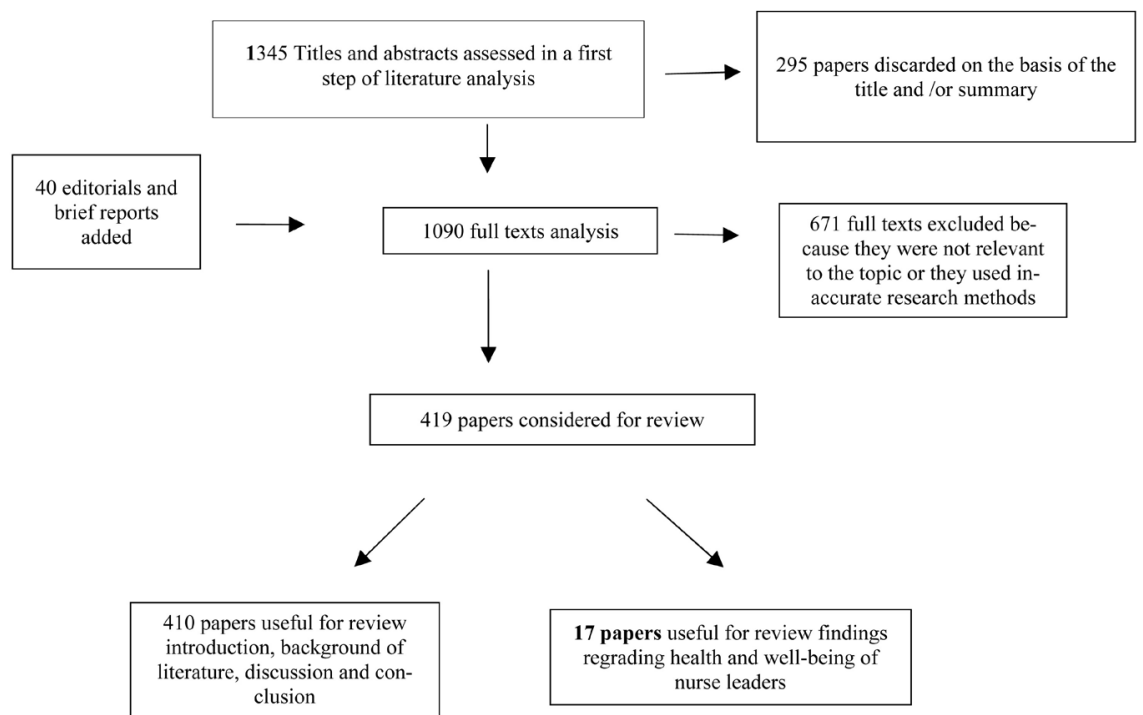

Figure 1. Search and screening papers.

authors in terms of the inclusion and exclusion criteria, their centrality to the review's aims and their quality, proceeding to their further assessment for selection. Among the discarded papers (671 in total) there are also those with no clear findings related to nurse managers/leaders included in the research sample and those involving samples of students. Finally, we focused solely on health and well-being among nurses with managerial and leadership functions, and a sample of 17 papers was identified for analysis.

\subsection{Data Analysis}

To analyze the final sample of 17 papers, we assessed the theoretical basis, as well as the editorial and scientific quality, of the studies using a specially designed model. This contained items such as: type of article, type of documentation used, focus on the topic of interest for our review, type of research, correctness of the design, method and analysis of data, relevance of research for the development of knowledge, effectiveness and clarity of communication of the information and findings. During this phase of quality appraisal, any disagreement between the two researchers was resolved through discussion and occasionally by appointing a third reviewer for mediation. The various topics emerging from the sample provided a general understanding of the state of the art concerning the review topic.

\section{Findings}

In this section, we shall present methodological aspects and findings of the reviewed papers. As all the papers presented methods involving empirical research, we also considered-along with the journal in which each article was published, the country, and the type of paper-the sample and the sampling method, the research design, the procedure, and the measurements used. The 
research findings were distinguished according to four main topics. This approach implied that reviewed papers could be quoted more than once if they dealt with more than one of the four topics considered.

\subsection{Method Used in the Reviewed Papers}

Table 1 summarizes particular methodological aspects of the 17 papers, most of which were published in international nursing and psychology journals. All papers presented empirical research, performed in European (such as Belgium,

Table 1. Methodological characteristics of the reviewed research projects.

\begin{tabular}{|c|c|c|c|c|c|}
\hline $\begin{array}{l}\text { Authors, year, } \\
\text { paper }\end{array}$ & Country & Setting & Sample & $\begin{array}{l}\text { Research design, measures and } \\
\text { procedure }\end{array}$ & Variables \\
\hline $\begin{array}{l}\text { Adriaenssens, } \\
\text { Hamelink \& Van } \\
\text { Bogaert (2017). } \\
\text { International } \\
\text { Journal of Nursing } \\
\text { Studies }\end{array}$ & Belgium & $\begin{array}{l}11 \text { Hospitals } \\
\text { and all Ward } \\
\text { types }\end{array}$ & $\begin{array}{l}318 \mathrm{FLNM}^{*} \\
60 \% \text { Female } \\
\text { Age }=46 \text { Years } \\
82 \% \text { bachelor } \\
85 \% \text { full-time } \\
19 \text { years of job experience } \\
12 \text { years } \mathrm{NM}^{*} \text { experience }\end{array}$ & $\begin{array}{l}\text { Cross-sectional, correlational } \\
\text { quantitative design } \\
\text { Validated tests } \\
\text { Online Administration of tests } \\
\text { Work Questionnaire for Nurses }\end{array}$ & $\begin{array}{l}\text { Job demands and control } \\
\text { Support Conflicts } \\
\text { Job satisfaction } \\
\text { Turnover } \\
\text { Anxiety Depression } \\
\text { Psychosomatic distress } \\
\text { Burnout }\end{array}$ \\
\hline $\begin{array}{l}\text { Duffy, Avalos \& } \\
\text { Dowling (2015). } \\
\text { International } \\
\text { Emergency } \\
\text { Nursing }\end{array}$ & Ireland & $\begin{array}{l}3 \text { Departments } \\
\text { of Teaching in } \\
\text { Hospitals }\end{array}$ & $\begin{array}{l}105 \text { registered nurses } \\
74.3 \% \mathrm{NS}^{*} \\
21 \% \mathrm{NM}^{*} \\
95 \% \text { Female } \\
19 \text { years of job experience } \\
\text { Age }=40 \text {-year range }(21-60 \\
\text { years) }\end{array}$ & $\begin{array}{l}\text { Cross-sectional, correlational } \\
\text { quantitative design } \\
\text { Administration of tests in the } \\
\text { hospital } \\
\text { Validated tests and survey ad hoc for } \\
\text { stress relieving strategies }\end{array}$ & $\begin{array}{l}\text { Post Traumatic Stress } \\
\text { Disorder (PTSD) } \\
\text { r }\end{array}$ \\
\hline $\begin{array}{l}\text { Heeb \& } \\
\text { Haberey-Knuessi, } \\
\text { (2014). Nursing } \\
\text { Research and } \\
\text { Practice }\end{array}$ & Switzerland & $\begin{array}{l}\text { University, } \\
\text { Local, } \\
\text { Regional } \\
\text { Hospitals }\end{array}$ & $\begin{array}{l}257 \mathrm{NM}^{*} \\
60 \% \text { Female } \\
\text { Age }=46.7 \text { years } \\
91 \% \text { university education } \\
63.8 \%>16 \text { years of job } \\
\text { experience; } 30.4 \% \text { up to } 5 \\
\text { years } \mathrm{NM}^{\star} \text { experience }\end{array}$ & $\begin{array}{l}\text { Cross-sectional, correlational } \\
\text { quantitative design } \\
\text { Administration of tests in the } \\
\text { hospital } \\
\text { Standardized electronic } \\
\text { questionnaire }\end{array}$ & $\begin{array}{l}\text { Personal, Job, Organization } \\
\text { characteristics } \\
\text { Burnout }\end{array}$ \\
\hline $\begin{array}{l}\text { Hewko, Brown, } \\
\text { Fraser, Wong \& } \\
\text { Cummings (2015). } \\
\text { Journal of Nursing } \\
\text { Management }\end{array}$ & Canadian & $\begin{array}{l}\text { Acute care, } \\
\text { General } \\
\text { Long-Term } \\
\text { Care } \\
\text { Hospitals }\end{array}$ & $\begin{array}{l}95 \mathrm{FL} \mathrm{NM}^{*} \\
92 \% \text { Female } \\
\text { Age }=40-59 \text { years }\end{array}$ & $\begin{array}{l}\text { Part of wider research project } \\
\text { Cross-sectional, correlational } \\
\text { quantitative design } \\
\text { Web administration of survey } \\
\text { Validated tests }\end{array}$ & $\begin{array}{l}\text { Role, job and personal } \\
\text { variables } \\
\text { Burnout }\end{array}$ \\
\hline $\begin{array}{l}\text { Hudgins (2016) } \\
\text { Journal of Nursing } \\
\text { Management }\end{array}$ & Virginia & $\begin{array}{l}\text { Multi-Hospital } \\
\text { Health-care }\end{array}$ & $\begin{array}{l}495 \mathrm{NL}^{*} \\
80 \% \text { White } \\
186.5 \% \text { Female } \\
\text { Age }=47.33 \text { years } \\
36 \% \text { Masters degree } \\
88.8 \% \text { full time }\end{array}$ & $\begin{array}{l}\text { Cross-sectional, correlational } \\
\text { quantitative design } \\
\text { Web administration of the survey. } \\
\text { Validated tests } \\
\text { Single-item job satisfaction and the } \\
\text { anticipated turnover }\end{array}$ & $\begin{array}{l}\text { Resilience } \\
\text { Job satisfaction } \\
\text { Anticipated turnover }\end{array}$ \\
\hline $\begin{array}{l}\text { Kath, Stichles \& } \\
\text { Ehrhart (2012) } \\
\text { Journal of } \\
\text { Nursing } \\
\text { Administration }\end{array}$ & U.S & $\begin{array}{l}36 \text { Acute-care } \\
\text { Hospitals }\end{array}$ & $\begin{array}{l}480 \mathrm{NM}^{*} \\
90 \% \text { Female } \\
\text { Age }=48 \text { years }\end{array}$ & $\begin{array}{l}\text { Cross-sectional, correlational } \\
\text { quantitative design } \\
\text { Validated tests } \\
\text { Survey administration during } \\
\text { nursing leadership meetings }\end{array}$ & $\begin{array}{l}\text { Job stress, Autonomy } \\
\text { Social support, Job } \\
\text { satisfaction, Organizational, } \\
\text { Commitment, Turnover } \\
\text { intention, Physical and } \\
\text { Mental Health }\end{array}$ \\
\hline
\end{tabular}




\section{Continued}

\begin{tabular}{|c|c|c|c|c|c|}
\hline $\begin{array}{l}\text { Kath, Stichles, } \\
\text { Ehrhart \& Schultze, } \\
\text { (2013b). JOGNN }\end{array}$ & $\begin{array}{l}\text { North } \\
\text { United } \\
\text { "States and } \\
\text { Canada }\end{array}$ & $\begin{array}{l}\text { Community } \\
\text { Academic, } \\
\text { Nursing } \\
\text { Homes, } \\
\text { Military }\end{array}$ & $392 \mathrm{NL}^{*}$ & $\begin{array}{l}\text { Cross-sectional, correlational } \\
\text { quantitative design } \\
\text { Validated tests } \\
\text { Survey online or by mail }\end{array}$ & Stress \\
\hline $\begin{array}{l}\text { Matsuzaki, } \\
\text { Uemura \& Yasui } \\
\text { (2014) Maturitas }\end{array}$ & Japan & $\begin{array}{l}\text { Public and } \\
\text { Private } \\
\text { Hospitals }\end{array}$ & $\begin{array}{l}338 \mathrm{NS}^{*} \\
514 \mathrm{NM}^{*} \\
\text { Age }=45-60 \text { years }\end{array}$ & $\begin{array}{l}\text { Cross-sectional, correlational } \\
\text { quantitative design } \\
\text { Self-administered questionnaire } \\
\text { Validated tests }\end{array}$ & $\begin{array}{l}\text { Menopause symptoms } \\
\text { Stress }\end{array}$ \\
\hline $\begin{array}{l}\text { Rudolfsson \& } \\
\text { Flensner (2012) } \\
\text { Journal of Nursing } \\
\text { Management }\end{array}$ & Sweden & $\begin{array}{l}\text { Hospitals, } \\
\text { Nursing Units }\end{array}$ & $\begin{array}{l}10 \mathrm{NL}^{*} \\
8 \text { Male } \\
\text { Age }=41-58 \text { years } \\
\text { All registered nurses }\end{array}$ & $\begin{array}{l}\text { Part of wider research project } \\
\text { Hermeneutical approach and an } \\
\text { open-ended audio-taped interview }\end{array}$ & Meaning of suffering \\
\hline $\begin{array}{l}\text { Sherman, } \\
\text { Schwarzkopf \& } \\
\text { Kiger (2011) } \\
\text { International } \\
\text { Scholarly } \\
\text { Research Network } \\
\text { ISRN Nursing }\end{array}$ & $\begin{array}{l}\text { South } \\
\text { Florida }\end{array}$ & $\begin{array}{l}10 \text { Tenet } \\
\text { Health } \\
\text { facilities }\end{array}$ & $\begin{array}{l}354 \text { Charge Nurses } \\
\text { Age }=46.5 \text { years } \\
19.5 \text { years of job experience } \\
55 \% \text { associate degree or a } \\
\text { diploma degree }\end{array}$ & $\begin{array}{l}\text { Cross-sectional, correlational } \\
\text { quantitative design } \\
\text { A survey with five open and } \\
\text { closed-ended questions designed by } \\
\text { the authors }\end{array}$ & $\begin{array}{l}\text { Leadership } \\
\text { Job role satisfaction } \\
\text { Factors Impacting Movement } \\
\text { into Leadership Roles }\end{array}$ \\
\hline $\begin{array}{l}\text { Shirey, McDaniel, } \\
\text { Ebright, Fisher \& } \\
\text { Doebbeling (2010). } \\
\text { Journal of Nursing } \\
\text { Administration40 }\end{array}$ & U.S. & $\begin{array}{l}3 \text { Acute Care } \\
\text { Hospitals }\end{array}$ & $\begin{array}{l}21 \mathrm{NM} \\
95 \% \text { Female } \\
\text { Age }=37-62 \text { years } \\
67 \% \text { married } \\
29 \% \text { with children } \\
12 \text { - } 35 \text { years of job } \\
\text { experience; } 1.5 \text { - } 18 \text { years } \\
\mathrm{NM}^{\star} \text { experience }\end{array}$ & $\begin{array}{l}\text { Cross-sectional, correlational } \\
\text { qualitative design } \\
\text { Interviews with Critical Decision } \\
\text { Method (CDM). Three research } \\
\text { questions about stressors, coping } \\
\text { strategies and health-related } \\
\text { outcomes }\end{array}$ & $\begin{array}{l}\text { Stress } \\
\text { Emotions } \\
\text { Coping } \\
\text { Psychological and Physical } \\
\text { Health } \\
\text { Functional ability }\end{array}$ \\
\hline $\begin{array}{l}\text { Suzuki, et al. } \\
\text { (2009). }\end{array}$ & $\begin{array}{l}\text { Tohoku } \\
\text { Kanto, } \\
\text { Tokai } \\
\text { districts }\end{array}$ & $\begin{array}{l}3 \text { University } \\
\text { Hospitals }\end{array}$ & $\begin{array}{l}172 \mathrm{NM}^{*} \\
\text { Age }=43.8 \text { years for burnout } \\
\text { group } \\
\text { Age }=44.1 \text { years for } \\
\text { no-burnout group }\end{array}$ & $\begin{array}{l}\text { Cross-sectional, correlational } \\
\text { quantitative design } \\
\text { Self-administered questionnaire }\end{array}$ & $\begin{array}{l}\text { Burnout, Assertiveness } \\
\text { Turnover intention, Job } \\
\text { satisfaction, Social support } \\
\text { and coping profiles, Job } \\
\text { Perception }\end{array}$ \\
\hline $\begin{array}{l}\text { Udod, Cummings, } \\
\text { Care, Jenkins } \\
\text { (2017) JONA }\end{array}$ & $\begin{array}{l}\text { Western } \\
\text { Canada }\end{array}$ & $\begin{array}{l}8 \text { Urban and } \\
\text { Rural Acute } \\
\text { Care } \\
\text { Settings }\end{array}$ & $\begin{array}{l}23 \mathrm{NM}^{*} \\
91 \% \text { Female } \\
\text { Age }=26-61+\text { years } \\
43 \% 41-50 \text { years } \\
57 \% 20-35 \text { years of job } \\
\text { experience } \\
52 \% \text { NM having > } 100 \\
\text { individuals to supervise. Years } \\
\text { as a NM } 5.0 \text { years }\end{array}$ & $\begin{array}{l}\text { Cross-sectional, correlational } \\
\text { qualitative design } \\
\text { Individual interviews and focus } \\
\text { group interviews } \\
\text { Contact with senior nurse } \\
\text { administrators. } \\
\text { The focus group interview was } \\
\text { facilitated by the nurse researcher, } \\
\text { and field notes taken by the research } \\
\text { assistant. }\end{array}$ & $\begin{array}{l}\text { Role stressors } \\
\text { Coping strategies }\end{array}$ \\
\hline $\begin{array}{l}\text { Van Bogaert, et al. } \\
\text { (2014). Journal of } \\
\text { Advanced Nursing }\end{array}$ & $\begin{array}{l}\text { Belgium } \\
\text { (Flemish) }\end{array}$ & $\begin{array}{l}17 \text { Acute Care } \\
\text { Hospitals }\end{array}$ & $\begin{array}{l}365 \mathrm{NM}^{*} \\
\text { Age }=44.1 \text { years } \\
11.8 \text { years of job experience; } \\
11.6 \text { years of } \mathrm{NM} \text { work } \\
\text { experience } \\
57.5 \% \text { baccalaureate degrees; } \\
80.5 \% \text {, additional } \\
\text { management; } 76.4 \% \\
\text { leadership training } \\
89.6 \% \text { full-time position }\end{array}$ & $\begin{array}{l}\text { Cross-sectional, correlational } \\
\text { quantitative design } \\
\text { Self-administered structured } \\
\text { questionnaire } \\
\text { Validated tests }\end{array}$ & $\begin{array}{l}\text { Job role } \\
\text { Job Demand-Control-Support } \\
\text { Organizational variables } \\
\text { Burnout, Emotional } \\
\text { exhaustion, Vigor, } \\
\text { Dedication, Absorption } \\
\text { Quality of Work, } \\
\text { Work Engagement }\end{array}$ \\
\hline
\end{tabular}




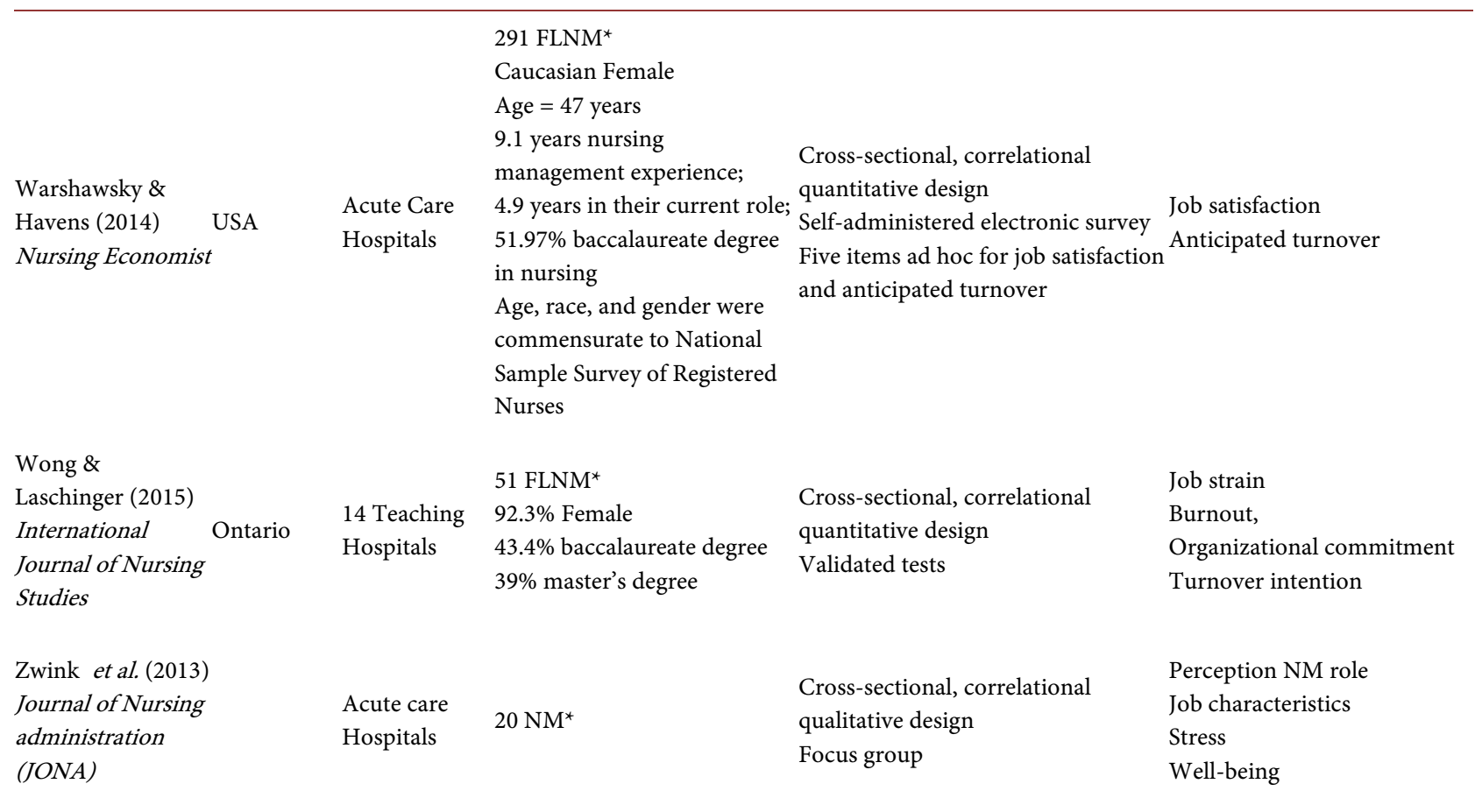

Key: ${ }^{\star} \mathrm{NM}=$ Nurse Manager; FLNM = First-line Nurse managers; NL = Nurse Leaders; NS = Nurse Staff.

Ireland, Switzerland) and the most part extra-European countries (such as American countries, Japan). In two of them, the report was part of a wider study [53] [54]. For instance, Hewko et al. [53] presented the second phase of three phases of Quality Work Environment Study (QWEST) about the resonant leadership practices of first-line patient care managers. The wider project of $\mathrm{Ru}$ dolfsson and Flensner [54] regarded what constitutes caring in a perioperative culture. Most researches used cross-sectional design and quantitative descriptive data analysis. However, certain studies also chose a qualitative descriptive research design, using interviews and, in some cases, focus groups [54] [55] [56] [57]. In particular, Rudolfsson and Flensner [54] asked participants to relate about their experiences of suffering at work, answering to questions such as "What constitutes suffering in your work?" Instead Shirey et al. [55] employed a face to face interview that incorporated components of a retrospective interview methodology (the Critical Decision Method/CDM), for describing Nurse Managers' experience.

The samples were generally suitable and some of them also included nursing staff [58] [59]. In certain cases, scholars proposed a definition of the role of nurses with a leadership and management function. For example, Matsuzaki et al. [59] chose nurse managers whose managerial position involves the direction of a nursing department, or head nurses; Shirey et al. [55] define the nurse manager as a Registered Nurse (RN) "holding the title of nurse manager for 1 year or more and having 24-hour accountability for at least 1 patient care unit" (83). Warshawsky and Havens [60] include in the sample "first-line manager of 
a patient care area(s) with 24-hour responsibility for the operational, fiscal, and performance accountability" (pg. 3).

Participants are usually selected by contacting the hospital [56] or the same trade associations [60] [61] and included mostly women of variable ages, with the average age lying between 40 and 48 years. The participants' job experience in the management and leadership role in some cases is between 5 and 8 years [46] [56], whilst in others it is higher: up to 12 years in the research sample collected by Adriaenssens, Hamelink and Van Bogaert [62] and up to 16 years in the sample collected by Heeb and Haberey-Knuessi [63]. In terms of the measures employed to assess the various variables treated in the studies, in the majority of cases self-reports-sometimes completed online-were used [53] [61]. For instance Kath et al. [61] invited nurse leaders by postcard to participate in an online survey.

\subsection{Topics and Main Findings of the Reviewed Papers}

Table 2 summarizes the main research topics, the theoretical basis, and main findings of each of the papers reviewed.

In general, most of the 17 papers remarked the centrality of nurses with managerial and leadership functions in healthcare quality, even though-as affirmed by certain scholars-it is a complex and ambiguous role mainly due to

Table 2. Authors, paper title, topic, objectives and main research finding of the reviewed papers.

\begin{tabular}{|c|c|c|}
\hline Authors and paper title & Topic, Objectives of the reviewed papers & Main Findings of the reviewed papers \\
\hline $\begin{array}{l}\text { Adriaenssens, et al. (2017). } \\
\text { Predictors of occupational } \\
\text { stress and well-being in } \\
\text { First-Line Nurse Managers: } \\
\text { A cross-sectional survey } \\
\text { study. }\end{array}$ & $\begin{array}{l}\text { Risk and protective factors of stress and } \\
\text { health } \\
\text { Analyzing if job requests, job control, } \\
\text { social support and inter-professional } \\
\text { conflicts are predictors of } \mathrm{NM}^{\star} \text { job stress } \\
\text { and well-being (job satisfaction). }\end{array}$ & $\begin{array}{l}\text { Various associations between predictors and outcomes and Job } \\
\text { Demand-Control-Support model is confirmed } \\
\text { Positive perception of work/timedemands is associated with lower levels } \\
\text { of psychosomatic distress and burnout and higher levels of job } \\
\text { satisfaction. } \\
\text { Job control and social support of the staff team are important predictors } \\
\text { of NM's occupational well-being and the inter-professional } \\
\text { collaboration of job satisfaction } \\
\text { No association between physical demand and outcomes and between } \\
\text { social support of colleagues and well-being }\end{array}$ \\
\hline $\begin{array}{l}\text { Duffy, et al. (2015). } \\
\text { Secondary traumatic stress } \\
\text { among emergency nurses: a } \\
\text { cross-sectional study }\end{array}$ & $\begin{array}{l}\text { Secondary traumatic stress }(S T S) \\
\text { The study measured emergency } \\
\text { department nurses' self-reported levels of } \\
\text { secondary traumatic stress. }\end{array}$ & $\begin{array}{l}\text { Poor level of STS in CNM }{ }^{*} \\
\text { The highest proportion }(82 \%) \text { of STS existed in the nurse staff group } \\
\text { No other findings about CNM but the total sample }\end{array}$ \\
\hline $\begin{array}{l}\text { Heeb \& Haberey-Knuessi, } \\
\text { (2014). Health professionals } \\
\text { facing burnout: What do we } \\
\text { know about nursing } \\
\text { managers? }\end{array}$ & $\begin{array}{l}\text { Burnout } \\
\text { Burnout prevalence in } \mathrm{NMs}^{*} \text { and its } \\
\text { association with personal, job and } \\
\text { organizational characteristics. } \\
\text { Are } \mathrm{NMs}^{*} \text { vulnerable to burnout due to } \\
\text { their role features? }\end{array}$ & $\begin{array}{l}\text { Low incidence of burnout on NMs in Switzerland } \\
\text { In NMs higher variation of burnout related to their emotional } \\
\text { exhaustion: } \\
\text { Similar burnout between physicians and NMs }\end{array}$ \\
\hline $\begin{array}{l}\text { Hewko, et al. (2015). } \\
\text { Factors influencing nurse } \\
\text { managers' intent to stay or } \\
\text { leave: A quantitative } \\
\text { analysis }\end{array}$ & $\begin{array}{l}\text { Burnout and Nurse Manager turnover } \\
\text { Is burnout a risk factor of NM turnover? }\end{array}$ & $\begin{array}{l}\text { Burnout is a risk factor of NM turnover. NMs intending to stay in their } \\
\text { role reported more job and love satisfaction than those intending to } \\
\text { leave. The latter reported greater emotional exhaustion than managers } \\
\text { intending to stay. }\end{array}$ \\
\hline
\end{tabular}




\section{Continued}

Hudgins (2016)

Resilience, job satisfaction, and anticipated turnover in nurse leaders

Kath, et al. (2012)

Moderators of the Negative Outcomes of Nurse Manager Stress

\section{Job satisfaction, resilience, and NL Turnover}

Relationships between resilience, job satisfaction, and anticipated turnover among nurse leaders.

\section{Effects of job stress}

Research Questions:

"What are the levels of perceived job stress for nurse managers?

What outcomes are associated with higher levels of job stress?

What hospital, job, or psychosocial characteristics buffer the negative outcomes of job stress?" (pg. 216)

\section{Effects of job stress}

\section{Research questions:}

Kath, et al. (2013b). Predictors and outcomes of nurse leader job stress experienced by AWHONN members

Matsuzaki, et al. (2014). "What are the relationships among stressors (personal factors, job/role factors, hospital factors), job stress, and outcomes experienced by nurse leaders? Are the outcomes of job stress moderated by autonomy and leadership style?" (pg. E15)

\section{Stress and health}

Effects of job-related stress factors on typical menopausal symptoms, such as Associations of menopausal feelings of tiredness, irritability and symptoms with job-related difficulty in concentration. stress factors in nurses in Japan

To investigate differences in menopausal symptoms and job-related stress among nurses in managerial positions and those not in managerial positions

Rudolfsson \& Flensner (2012) Suffering and suffering with the other-the perspective of perioperative nurse leaders

Sherman, et al (2011). Charge Nurse Perspectives on Frontline Leadership in Acute Care Environments

Shirey, et al. (2010). Understanding nurse manager stress and work complexity: Factors that make a difference

Suzuki et al. (2009). Relationship between assertiveness and burnout among nurse managers

\section{Effects of stress}

\section{Suffering in nurse leaders}

Meanings of suffering from the perspective A main theme of suffering from the perspective of nurse leaders of perioperative nurse leaders, using a hermeneutical approach

\section{Job satisfaction and leadership}

To examine leadership qualities needed today in nursing roles; the challenges, and Participants identified a large number of role satisfiers. role satisfiers from the perspective of the frontline nurse leader.

Other than the stress effects, stressful situations and coping strategies among $\mathrm{NM}^{\star}$ are considered

\section{Protective factors of burnout}

Assertiveness as protective factor of burnout among $\mathrm{NMs}^{\star}$

The role of confounding factors in the assertiveness-burnout association emerged as learning and non-learning suffering.

$\mathrm{NMs}^{\star}$ like their job (91\%)

$14 \%$ turnover intention

All nurse managers report both negative and positive emotions $67 \%$ reported adverse psychological outcomes. burnout. due to numerous confounding factors.
Relationship between NL's resilience and job satisfaction and between job satisfaction and anticipated turnover. Resilience has a significant relationship with a nurse leader's intent to remain in a leadership position.

Job stress was positively associated with physical and mental symptoms thely with job satisfaction. The effects of job stress are moderated by autonomy, job predictability and social support.

High levels of stress in $\mathrm{NL}^{\star}$, mainly in those having supervisory responsibilities.

Stress effects are: poor job satisfaction, more turnover intention and poor mental health

Mediators are: autonomy that buffers the effect of stress on job satisfaction, on mental health symptoms and on turnover intentions.

Besides the menopausal symptoms were not significantly different between nurses in managerial positions and nurse staff, the first group reported more feelings of unhappiness or depression and crying spells than the second group. Also, among the nurses in managerial positions low levels of job fitness and satisfaction were correlated with psychological symptoms.

$86 \%$ reported adverse physiological outcomes from role-related stress.

The higher the assertiveness score was, the lower the prevalence of

Significant differences between the burnout and non-burnout groups 


\section{Continued}

Udod, et al. (2017) Impact of Role Stressors on the

Health of Nurse Managers

Van Bogaert, et al. (2014). Impact of role-, job- and organizational characteristics on Nursing Unit Manager work-related stress and well-being

Warshawsky \& Havens (2014) Nurse manager job satisfaction and intent to leave

Wong \& Laschinger (2015) The influence of frontline manager job strain on burnout, commitment and turnover intention: A cross-sectional study

Zwink et al. 2013 Nurse Manager Perceptions of Role Satisfaction and Retention at an Academic Medical Center

\section{Stress-health}

Role stressors, coping strategies and their impact on the health of $\mathrm{NMs}^{\star}$

\section{Stress and well-being}

The impact of organization, role and job features on stress perception and

well-being among $\mathrm{NMs}^{\star}$

Job satisfaction and turnover intention To examine presence and levels of $\mathrm{NM}^{*}$ job satisfaction and intent to leave his/her positions.

\section{Effects of Job strain}

The effects of frontline manager job strain causing their burnout (emotional exhaustion and cynicism), organizational commitment and turnover intentions.

\section{Job satisfaction and turnover}

To explore and describe the role of $\mathrm{NMs}^{\star}$ and to identify opportunities to increase job satisfaction and the balance between job and private life.

Characteristics in relation to the development of work related stress, well-being, and work engagement.
The findings support the application of the Lazarus and Folkman model as a method of understanding the relationships among the NM work environment, their stressful interactions, coping strategies, and perceptions on their health.

A more positive perception of organization, role and job features was associated with a decrease in emotional exhaustion and to higher levels of job satisfaction.

Role conflict and role meaningfulness predicted various outcomes such as emotional exhaustion, job satisfaction...

High level of job satisfaction associated with the intention to stay in their position. Many participants provided a primary reason for intent to leave their position in the next 5 years is related to JS*.

Emotional exhaustion by means of the relationship between job strain and cynicism and cynicism by means of the relationships between emotional exhaustion and organizational commitment and turnover intention.

A robust positive relationship was identified between job strain and burnout: increased emotional exhaustion followed by increased cynicism.

The difficulty of job and private life balance as a risk factor for emotional exhaustion.

Factors associated to burnout are workload issues, work-life imbalance, and difficulty sustaining positive relationships.

Key: ${ }^{\star} \mathrm{NM}=$ Nurse Manager; NMs = Nurse Managers; $\mathrm{CNL}=$ Clinical Nurse Manager; FLM = Frontline Manager; NLs = Nurse Leaders; JS = Job Satisfaction.

the increase in the past years of mainly management responsibilities and to the new challenges caused by continuous changes in the healthcare setting [55] [60] [62] [63] [64] [65].

In terms of the structural and managerial changes in the health system (above all targeted towards business management and production efficiency), Heeb and Haberey-Knuessi [63] recognized how the changes have affected the meaning and objectives attributed to the nurse leader job itself in Switzerland.

In the view of certain scholars, nursing research focused mainly on workplace stressors and job commitment [54] [57] [58] [62], but it directed poor focus on nursing leadership, health management and well-being. Therefore, the aim of the most reviewed research projects is simply to fill the knowledge gap, making contributions concerning the specific dimensions and aspects of research. For instance, Heeb and Haberey-Knuessi [63] reported that besides the large literature on burnout, we know little about its prevalence and its risk factors on nurse managers. Instead, Kath et al. [46] recognized the paucity of interest concerning the outcomes of nurse manager stress, and Matsuzaki et al. [59] affirmed the lack of material related to the typical menopausal symptoms in that the most 
part of the nursing workers are women. Warshawsky and Havens [60] reported lack of literature concerning job satisfaction, and Rudolfsson and Flensner [54] reported how at the wide attention given to suffering diseases is not equally dealt with in terms of nurse leaders. Certain scholars, such as Sherman, Schwarzkopf and Kiger [66] affirmed that nurses are often placed in leadership positions without having the needed competencies and skills to meet the challenges that the role involves.

In terms of stress and its effects, Lazarus and Folkman's theory [67] is the most citied. It allows understanding the complex dynamics involving the personal and work-related demands of nurse manager/leader roles and the consequent effects on health [56]. It also allows focusing on specificity of the population being analyzed, stressful situations and events experienced by the people who hold different professional roles, and stress effects on the workers' occupational well-being [62]. Other models that provide a theoretical framework for the reviewed papers concern the interaction between job demands and resources to explain the reactions to stressful situations, such as the Demand-Control-Support Model [68]. This model allows observing the interaction between job demands (that may be risk factors) and resources (that reduce the demand outcomes and may be a source of individual development and growth). More specifically, Kath et al. [46] believed that this model is a relevant theoretical framework for the assessment of the effects of interaction among job demands, work control, and social support. They hypothesized nurse manager job stress may have negative outcomes only if the higher demands (stressors) match the low job control (autonomy) and poor social support by supervisors and colleagues. Even Adriaenssens et al. [62] accounted job resources as a key factor in the nurse manager's control on his/her tasks, functions, and social support.

The research aims proposed in the reviewed papers are at times broader than our review topic. For instance, certain scholars considered stress risk factors and the various stressful situations that nurses in managerial and leadership functions may face [55] [61] [62] [64]; others, such as Sherman et al. [66], focused on required skills and abilities, as well as the job challenges faced, in addition to nurses' job satisfaction; Zwink et al. [57] were interested in exploring and describing the nurse manager role, his/her perception of the job setting, and on finding the opportunity to improve work satisfaction and the balance between work and private life.

\subsection{Perception and Prevalence of Health and Well-Being}

The question dealt with in this section is: what are the levels of physical and mental health, well-being, job satisfaction, and burnout perceived by nurses who hold coordinator, leadership, and management positions? We can see that most of the researches that answer the question focused on job satisfaction, stress, and burnout.

Generally speaking, nurse managers and nurse leaders reported a good level of 
Job satisfaction. $91 \%$ of nurse managers of the sample in the research by Shirey et al. [55] likes their work; Warshawsky and Haven [60] observed that 29\% of nurse managers were very satisfied with their job position, while $41 \%$ were satisfied, $27 \%$ were very likely and $41 \%$ were likely to recommend nursing management as a career. In terms of the specific aspects of job satisfaction, Warshawsky and Haven [60] found that $52 \%$ of those interviewed were either satisfied or very satisfied with the amount of time available to work with staff. Sherman et al. [66] noted that, despite the challenges in the role of frontline leadership faced by charge nurses, the latter report a number of satisfying aspects of their work, such as the opportunity to develop staff, improving staff management ability, improving their skills in effectively organizing and solving problems, knowing that their role makes a difference and they can contribute to the maintenance of quality and safety of healthcare settings.

As for burnout, Heeb and Haberey-Knuessi [63] found its level to be low among nurse managers due to the presence of resources such as education and job autonomy that help these professionals to cope with stressful situations. Among burnout outlets, emotional exhaustion and depersonalization are the most frequent, mainly among women and nurse managers with poor experience.

Stressful situations have higher levels among nurse managers of the sample in the research by Udod et al. [56] and among nurse leaders in the research by Kath et al. [61], with a higher number recorded among those who have supervisory responsibilities and work in acute-care and urban settings than those in no acute-care and suburban/rural settings.

Mental and physical health have not been sufficiently analyzed, and received attention mainly in terms of certain specific aspects. For instance, Duffy et al. [58] detected a low frequency-among clinical nurse managers (14.9\%) who work in emergency department-of secondary traumatic stress (STS), which concerns the physical and psychological outcomes of stress experienced by those who help suffering or traumatized people. Matsuzaki et al. [59] reported higher levels of typical menopausal symptoms (feeling tired or lacking energy, difficulty in concentration, feeling tense or nervous, feeling unhappy or depressed) both among nurse managers and nurse staff, without differences between the two groups. Nevertheless, nurse managers reported more frequent feelings of unhappiness, depression, and crying spells than other nurses, perhaps due to the high degrees of their psychological stress, having to deal with medical issues and human resource management. Rudolfsson and Flensner [54] focused on the meaning of suffering from the perspective of perioperative nurse leaders; suffering was defined both as learning (suffering as a possibility of personal development) and non-learning. They also observed the presence of both types in nurse managers. In particular, suffering as non-learning "was constituted by the meanings of 'feeling alone when in charge', 'feeling guilty about not managing daily tasks', 'feeling mistrusted by superiors', 'feeling unfairly criticized', 'feeling humiliated owing to loss of responsibilities' and 'feeling unable to help'” (pg. 281). 


\subsection{Risk Factors of Health and Well-Being}

Work stress is an important risk factor for both physical and mental health and job satisfaction among nurses with managerial and leadership positions [46] [61]. For instance, Kath et al. [61] found that stress may create a poor job satisfaction and an increase in mental health symptoms and turnover intention. Wong and Laschinger [65] observed association among job strain and higher emotional exhaustion and cynicism. Shirey et al. [55] viewed that $67 \%$ of nurse managers react to stressful job situations with adverse psychological outcomes-such as mental acuity and personality changes, loss of confidence, anxiety, restless mind and emotional exhaustion-and $86 \%$ react with adverse physiological outcomes (sleep disorders, physical exhaustion, and high blood pressure). Udod et al. [56] reported that nurse managers frequently facing role stressors might have psychological (emotional exhaustion and inability to communicate it, or depression) and physical (sleep disorders, weight increase or loss) outcomes, as well as family strain (unloading the negativity of the working day on the spouse and the family).

Key burnout causes in nurses with management and leadership functions seem to be role overload (regarding the perception of discrepancy between the amount of work and the time required to perform it), role conflict, and role ambiguity, related in particular to the conflicting demands of the health organization and nurse staff [55] [61] [64]. Other than role conflict and overload, Van Bogaert et al. [64] suggested that risk factors of emotional exhaustion are decision-making authority, collaboration with physicians, work agreements, and interference between job and private life. In addition to causes due to working roles as risk factors in terms of nurse manager health and well-being, Heeb and Haberey-Knuessi [63] identified job situations associated to burnout and, in particular, to emotional exhaustion. It seems there is an increasing trend due to irregular work hours, frequent conflicts with staff, discrepancies between personal values and organizational ones, or also between personal abilities and job demands. They also found that workload and working overtime seems to reduce personal accomplishment.

Poor job satisfaction and poor job fitness have been associated with the presence of psychological symptoms among nurses with managerial positions as observed Matsuzaki et al. [59]. Instead, Zwink et al. [57] identified the inability to maintain a balance between work and private life as a contribution to the emotional exhaustion of nurse managers.

\subsection{Protective Factors of Health and Well-Being}

The most reviewed researches concerning protective factors of health and well-being among nurse managers and nurse leaders were related to job resources. Some of them showed the importance of work/time demands that-as stated by Adriaenssens et al. [62]—can limit the psychosomatic discomfort and burnout among nurse managers, and can also be associated with higher levels of 
job satisfaction. In other papers, the scholars recorded the important effects of positive perception of the job and its characteristics that-in the opinion of Van Bogaert et al. [64] - is associated with decreasing emotional exhaustion and increasing job satisfaction. A central role is also played by decisional independence as a protective factor of job well-being [62] [64], job satisfaction and mental health [61], and as a moderator of negative stress effects [46] [64]. Wong and Laschinger [65] sustained the importance of appropriate decision-making authority, as well as control over work and time balanced with work demands to avert the danger of burnout. Social support also appears to be a protective factor of the negative effects of stress [46]. Adriaenssens et al. [62] found that the nurse team support, and not the support of same-level colleagues, is a predictive factor of nurse managers' job well-being; the collaboration of physicians was instead recorded to be a source of job satisfaction. The scholars explained these findings upon recording that first line nurse managers spend most of their time with the nursing staff, while contact with others in the same role or with hospital management is more sporadic and formal.

Research concerning personal sources of health and well-being is scarce. Suzuki et al. [69] based their analysis on assertiveness, recording that a higher assertiveness is associated with a lower prevalence of burnout among nurse managers. They also observed certain differences between burnout and non-burnout groups in terms of social support, satisfaction with one's own provision of care, and the feeling that one's own job is helpful. Hudgings [70] focused on resilience, recording its association with job satisfaction and as a key for nurse leaders to stay in their role.

As opposed to the poor consideration of personality factors, the coping strategies in stressful situations in leadership nursing have received a good amount of interest. In general, problem-solving strategies are the most effective [55] and more frequent among experienced nurse managers than beginners who, instead, tend to favor emotional strategies and live psychological, functional, and physiological issues. The scholars proposed the example that often beginners in nurse manager roles tend to react with angriness towards difficulties and to let off steam with others instead of solving problems.

\subsection{Effects of Health and Well-Being State}

We have found that only one effect has been analyzed in all the reviewed papers. It is turnover intention, a frequent reaction to a negative health state among nurses with leadership and management functions. Generally, it is due to burnout [53] [60]. For instance, Hewko et al. [53] found that turnover intention among nurse managers was more associated with emotional exhaustion than among nurse leaders. The latter also expressed more job satisfaction and love toward their work than the first group. The finding was confirmed by Kath et al. [46] and Warshawsky and Havens [60] — in terms of nurse managers-and by Hudgins [70] in terms of nurse leaders. Nonetheless, the findings by War- 
shawsky and Havens [60] appear in opposition with the general tendency. In fact, their research proved that although $70 \%$ of first-line nurse managers affirmed to be satisfied of very satisfied with their job position, $72 \%$ of the sample provided at least one reason for turnover intention in the following 5 years. It is a finding that-as affirmed by the scholars-needs further development, as it does not correspond to most findings involving the nursing field, which record a frequent association between job dissatisfaction and turnover intention.

\section{Discussion}

The aim of this paper was to analyze the state of literature concerning health and well-being among nurses with management and leadership functions, as well as the most important risks and protective factors and outcomes. The reviewed papers revealed the lack of scientific attention toward these topics, despite the international empirical literature recognized the presence of important vulnerabilities in such professionals.

In terms of the quality of the research method, we have observed certain tendencies and limits which still make it difficult to generalize the findings, and have found a number of random associations, which is recognized as a limit even by several authors [55] [64]. In the group of reviewed papers, priority is given to a cross-sectional research design and quantitative analyses, based on data obtained through the use of various standardized tools. Generally speaking, the tools are self-administered and are subject to potential bias [46]. Certain researchers used the qualitative method, relying on interviews and sometimes focus groups-allowing having more extensive answers to the questions proposed. Moreover, certain studies, while trying to detect disease states, did not use diagnostic tools, and for this reason-as claimed by Heeb and Haberey-Knuessi [63] - they did not allow to understand the clinical sense of the findings. In most cases, the research samples did not represent the population of nurses with managerial and leadership functions, and this can cause difficulty in generalizing the findings [60].

The reviewed papers generally highlighted the presence of risk and protective factors specific to the nursing management and leadership positions. The function or task (including staff support, management independence and education) confirms the usefulness of a job demand-control-support model to understand the risk and protective factors of stress, health, and well-being [62] [63]. Heeb and Haberey-Knuessi [63] found more similarities in terms of burnout between nurse managers and physicians rather than with nurse staff. This may be due to functions and convergence of positions between the two professional categories. In fact, in nurse managers the subordination of physicians is less accentuated than that of nurses, and the specificity of tasks between the two different positions may be less accentuated or in any case less important than the management functions.

While presenting certain gaps in the knowledge of the phenomenon, the re- 
view of findings allows to sustain the importance of developing on the subject both for further knowledge and to implement specific prevention programs for nurses with management and leadership functions. Such goal is central because the nursing professionals have a key role in efficient patient care and work environment quality [61].

The findings of the research papers involved in this review allow to delineate a number of basic tendencies to help nurse leaders. First of all, it is important to outline the key role of education and training (often underestimated), because the professionals may gain awareness and learn coping strategies to cope efficiently with stressful situations [71]. This calls for the implementation not only of curricular programs, but even training activities to develop leadership abilities and competencies [72]. The centrality that coping strategies as protective factors seem to have leads to the implementation of training programs centered precisely on learning such strategies. Experiential proposals are also interesting [73], as the expression and the sharing of the experiences may be a key source of stress prevention. The frequent presence of stressors, associated both to the management and leadership role and job setting, seem to direct the aim toward more systematic efforts to sensitize the healthcare administration on these topics, stimulating them to advance both the necessary measures to improve working conditions and the adequate support to lighten the workload among the professionals. It also appears that the proposed fixed supervision-as pointed out by Rankin, McGuire, Matthews, Russell and Ray [74]—can positively affect the clinical praxis and favor the professional development of nurse leaders and managers. On the other hand, as we have noted, social support-even that by administrators-is an important protective factor, which should be related-as stated by Kath et al. [46] — to the respect of the nurse leader/manager autonomy in ward management. Such support would be appropriate in developing a balance between support and freedom, also considering-as highlighted in various research papers-the loyalty conflict that these nurses often live as they play a role of intermediary between the administration and nursing staff/patients/family.

\section{Conclusions}

This review has allowed observing that research concerning nursing leadership health and well-being is still at an early stage.

While our systematic review allows having a general idea of the state of the art of knowledge and filling the gaps and critical issues concerning the interesting topic, there are certain considerations to be made. First of all, it must be specified that the selection of keywords was limited, and additional studies published between 2009 and 2018 were not considered because we only selected peer-reviewed journals in Italian and English language. Moreover, our review did not use meta-analysis, which may have enabled a more accurate understanding of the topic. This choice was based on the relatively poor state of knowledge concerning the topic, making it difficult to propose certain inferences on the importance, ef- 
fects, and ways of solving the issue. Therefore, the results and conclusions must be interpreted with caution. Another limitation of our study is that the narrative synthesis is an interpretation by the authors.

Despite these limits our review allows identifying challenges for future research concerning health and well-being in the field of nursing leadership. Firstly, we supported the need to maintain a research line that favors a scientific approach to the topic, having detected in empirical literature the presence of various papers based on opinions (that we have considered-in the present review-in the first phase related to general knowledge about the topic), which albeit can convey a broader picture of the analyzed topic, certainly do not help the progress of knowledge if not translated into research objectives. We also affirmed the necessity of a larger range of interesting in-depth studies in nursing literature including further risks and protective factors, also among nurse staff. For instance, among reviewed researches we have not found any papers concerning emotional regulation or emotional intelligence, which have been considered key factors for nursing health and well-being [12]. In addition, the balance between work and private life has been mentioned to a certain extent, but no research has been carried out concerning the work-family conflict, which is important in nursing research [75].

Future research should use a multidimensional design, incorporating different variables identified in nursing literature, in order to promote a more accurate and dynamic understanding of nursing leadership health and well-being. While their complex nature has been accepted in psychological literature, specific papers in the nursing field tend to focus mainly on particular dimensions, often associated to the authors' interests. A more careful rating of the differences in terms of situations, contexts, and roles within nursing, as well as personal characteristics, is often forgotten in the reviewed studies, while the latter should subscribe to the tendency toward complex research designs. Moreover, longitudinal data are needed to establish causality among specific stress or discomfort work situations lived by nurses with leadership and management functions, as well as their mental and physical health and well-being. In the papers we reviewed, none of the research projects used longitudinal design.

While our review highlighted interesting ideas for future research, it also permits to sustain the importance of an appropriate praxis. In fact, the possibility to prevent and treat the illness and dissatisfaction of nurse leaders and nurse managers appear important not only for these professionals, but also for the quality of their job, which involves the management of patient care, of patient families, and also of the nurse staff. A competent performance and a positive emotional state without suffering are essential to produce efficient and high-quality nursing care management. Therefore, it is desirable not only to increase awareness to promote further knowledge of the reviewed topic, but also to implement appropriate prevention and training programs, which may take into account the complexity of the variables involved in the assessment of discomfort, difficulties, 
health, and performance experienced by nurse managers and nurse leaders. Moreover, appropriate policies related to health services, that may direct more attention to the quality of workers' lives, can be important to face the nurse health sector issues. Certain researches already highlight the usefulness of these policies, such as the one conducted by Nejati, Shepley, Rodiek, Lee and Varni [76], who observed how the opportunity of adequate breaks during working hours and the creation of well-designed leisure areas can help improve the quality of working life.

\section{Conflicts of Interest}

The authors declare no conflicts of interest regarding the publication of this paper.

\section{References}

[1] Cañadas-De la Fuente, G.A., Vargas, C., San Luis, C., García, I., Cañadas, G.R. and De la Fuente, E.I. (2015) Risk Factors and Prevalence of Burnout Syndrome in the Nursing Profession. International Journal of Nursing Studies, 52, 240-249. https://doi.org/10.1016/j.ijnurstu.2014.07.001

[2] Maslach, C., Schaufeli, W.B. and Leiter, M.P. (2001) Job Burnout. Annual Review of Psychology, 52, 397-422. https://doi.org/10.1146/annurev.psych.52.1.397

[3] Steege, L.M., Drake, D.A., Olivas, M. and Mazza, G. (2015) Evaluation of Physically and Mentally Fatiguing Tasks and Sources of Fatigue as Reported by Registered Nurses. Journal of Nursing Management, 23, 179-189. https://doi.org/10.1111/jonm.12112

[4] Iliceto, P., Pompili, M., Spencer-Thomas, S., Ferracuti, S., Erbuto, D., Lester, D., Candilera, G. and Girardi, P. (2013) Occupational Stress and Psychopathology in Health Professionals: An Explorative Study with the Multiple Indicators Multiple Causes (MIMIC) Model Approach. The International Journal on the Biology of Stress, 16, 143-152. https://doi.org/10.3109/10253890.2012.689896

[5] Ali, A., Rasheed, A., Naz, S. and Siddiqu, M.A. (2018) A Study of Depression and Associated Factors among Nurses Working in Tertiary Care Hospitals in Karachi. Isra Medical Journal, 10, 138-142.

[6] Geiger-Brown, J., Trinkoff, A. and Rogers, V.E. (2011) The Impact of Work Schedules, Home, and Work Demands on Self-Reported Sleep in Registered Nurses. Journal of Occupational and Environmental Medicine (JOEM), 53, 303-307. https://doi.org/10.1097/JOM.0b013e31820c3f87

[7] Geiger-Brown, J., Rogers, V.E., Trinkoff, A.M., Kane, R.L., Bausell, R.B. and Scharf, S.M. (2012) Sleep, Sleepiness, Fatigue, and Performance of 12-Hour-Shift Nurses. Chronobiology International, 29, 211-219. https://doi.org/10.3109/07420528.2011.645752

[8] Hayes, B., Bonner, A. and Pryor, J. (2010) Factors Contributing to Nurse Job Satisfaction in the Acute Hospital Setting: A Review of Recent Literature. Journal of Nursing Management, 18, 804-814. https://doi.org/10.1111/j.1365-2834.2010.01131.x

[9] Fortunatti, C.P. and Palmeiro-Silva, Y.K. (2017) Effort-Reward Imbalance and Burnout among ICU Nursing Staff: A Cross-Sectional Study. Nursing Research, 66, 410-416. https://doi.org/10.1097/NNR.0000000000000239 
[10] Delgado, C., Upton, D., Ranse, K., Furness, T. and Foster, K. (2017) Nurses' Resilience and the Emotional Labour of Nursing Work: An Integrative Review of Empirical Literature. International Journal of Nursing Studies, 70, 71-88. https://doi.org/10.1016/j.ijnurstu.2017.02.008

[11] Geuens, N., Braspenning, M., Van Bogaert, P. and Franck, E. (2015) Individual Vulnerability to Burnout in Nurses: The Role of Type D Personality within Different Nursing Specialty Areas. Burnout Research, 2, 80-86.

https://doi.org/10.1016/j.burn.2015.05.003

[12] Gonnelli, C., Raffagnino, R. and Puddu, L. (2016) The Emotional Regulation in Nursing Work: An Integrative Literature Review and Some Proposals for Its Implementation in Educational Programs. IOSR Journal of Nursing and Health Science, 5, 43-49.

[13] Sharma, J., Dhar, R.L. and Tyagi, A. (2016) Stress as a Mediator between Work-Family Conflict and Psychological Health among the Nursing Staff: Moderating Role of Emotional Intelligence. Applied Nursing Research, 30, 268-275. https://doi.org/10.1016/j.apnr.2015.01.010

[14] Battistelli, A., Galletta, M., Vandenberghe, C. and Odoardi, C. (2016) Perceived Organizational Support, Organizational Commitment and Self-Competence among Nurses: A Study in Two Italian Hospitals. Journal of Nursing Management, 24, E44-E53. https://doi.org/10.1111/jonm.12287

[15] Gonnelli, C., Raffagnino, R. and Puddu, L. (2016) The Nurse Manager Training for an Efficient Leadership. INTED2016 Proceedings of 10 th International Technology, Education and Development Conference, Valencia, 7-9 March 2016, 543-551. https://doi.org/10.21125/inted.2016.1137

[16] Zito, M., Cortese, C.G. and Colombo, L. (2016) Nurses' Exhaustion: The Role of Flow at Work between Job Demands and Job Resources. Journal of Nursing Management, 24, E12-E22. https://doi.org/10.1111/jonm.12284

[17] Admi, H. and Eilon-Moshe, Y. (2016) Do Hospital Shift Charge Nurses from Different Cultures Experience Similar Stress? An International Cross-Sectional Study. International Journal of Nursing Studies, 63, 48-57. https://doi.org/10.1016/j.ijnurstu.2016.08.005

[18] Bender, M. (2014) The Current Evidence Base for the Clinical Nurse Leader: A Narrative Review of the Literature. Journal of Professional Nursing, 30, 110-123. https://doi.org/10.1016/j.profnurs.2013.08.006

[19] Mannix, J., Wilkes, L. and Daly, J. (2013) Attributes of Clinical Leadership in Contemporary Nursing: An Integrative Review. Contemporary Nurse, 45, 10-21. https://doi.org/10.5172/conu.2013.45.1.10

[20] Bender, M. (2016) Conceptualizing Clinical Nurse Leader Practice: An Interpretive Synthesis. Journal of Nursing Management, 24, E23-E31. https://doi.org/10.1111/jonm.12285

[21] Hartranft, S.R., Garcia, T. and Adams, N. (2007) Realizing the Anticipated Effects of the Clinical Nurse Leader. JONA, The Journal of Nursing Administration, 37, 261-263. https://doi.org/10.1097/01.NNA.0000277724.39079.9c

[22] Babine, R.L., Honess, C., Wierman, H.R. and Hallen, S. (2016) The Role of Clinical Nurse Specialists in the Implementation and Sustainability of a Practice Change. Journal of Nursing Management, 24, 39-49. https://doi.org/10.1111/jonm.12269

[23] Duffield, C.M., Roche, M.A., Blay, N. and Stasa, H. (2010) Nursing Unit Managers, Staff Retention and the Work Environment. Journal of Clinical Nursing, 20, 23-33. https://doi.org/10.1111/j.1365-2702.2010.03478.x 
[24] Miri, S.A., Mansor, N.A.A., Alkali, A. and Chikaji, A. (2014) The Role of First Line Nurse Manager. Review of European Studies, 6, 31-41. https://doi.org/10.5539/res.v6n4p31

[25] Cathro, H. (2016) Navigating through Chaos Charge Nurses and Patient Safety. JONA, The Journal of Nursing Administration, 46, 208-214.

[26] Wong, C.A., Cummings, G.G. and Ducharme, L. (2013) The Relationship between Nursing Leadership and Patient Outcomes: A Systematic Review. Journal of Nursing Management, 21, 709-724. https://doi.org/10.1111/jonm.12116

[27] Tingvoll, W.-A., Sæterstrand, T. and McClusky, L.M. (2016) The Challenges of Primary Health Care Nurse Leaders in the Wake of New Health Care Reform in Norway. BMC Nursing, 15, 66.

[28] Gaskin, C.J., Ockerby, C.M., Smith, T.R., Russell, V. and O'Connell, B. (2012) The Challenges Acute Care Nurse Unit Managers Face and the Strategies They Use to Address Them: Perceptions of Directors of Nursing and Nurse Unit Managers. Journal of Management \& Organization, 18, 625-640. https://doi.org/10.1017/S1833367200000572

[29] Gantz, N.R., Sherman, R., Jasper, M., Choo, C.G., Herrin-Griffith, D. and Harris, K. (2012) Global Nurse Leader Perspectives on Health Systems and Workforce Challenges. Journal of Nursing Management, 20, 433-443. https://doi.org/10.1111/j.1365-2834.2012.01393.x

[30] Cummings, G.G., Macgregor, T., Davey, M., Lee, H., Wong, C.A., Lo, E., Muise, M. and Stafford, E. (2010) Leadership Styles and Outcome Patterns for the Nursing Workforce and Work Environment: A Systematic Review. International Journal of Nursing Studies, 47, 363-385. https://doi.org/10.1016/j.ijnurstu.2009.08.006

[31] Germain, P.B. and Cummings, G.G. (2010) The Influence of Nursing Leadership on Nurse Performance: A Systematic Literature Review. Journal of Nursing Management, 18, 425-439. https://doi.org/10.1111/j.1365-2834.2010.01100.x

[32] Bobbio, A., Bellan, M. and Manganelli, A.M. (2011) Empowering Leadership, Perceived Organizational Support, Trust and Job Burnout for Nurses: A Study in an Italian General Hospital. Health Care Management Review, 37, 77-87. https://doi.org/10.1097/HMR.0b013e31822242b2

[33] Laschinger, H.K.S., Borgogni, L., Consiglio, C. and Read, E. (2015) The Effects of Authentic Leadership, Six Areas of Work Life, and Occupational Coping Self-Efficacy on New Graduate Nurses' Burnout and Mental Health: A Cross-Sectional Study. International Journal of Nursing Studies, 52, 1080-1089. https://doi.org/10.1016/j.ijnurstu.2015.03.002

[34] Bobbio, A., Manganelli Rattazzi, A.M. and Muraro, M. (2007) Empowering Leadership Style in Ambito Sanitario. Uno studio sul coordinatore infermieristico. Giornale Italiano di Medicina del Lavoro ed Ergonomia-Supplemento di Psicologia, 29, 37-49.

[35] Adatara, P., Kuug, A., Nyande, F., Opare, F.Y., Apaaye, M.A., Achaliwie, F. and Dotse, W. (2016) A Cross Sectional Study to Examine Perspective of Nursing Unit Managers on Factors Affecting the Effective Performance of Their Roles in the Volta Regional Hospital, Ghana. Pyrex Journal of Nursing and Midwifery, 2, 1-6. http://www.pyrexjournals.org/pjnm

[36] Lundgrén-Laine, H., Kalafati, M., Kontio, E., Kauko, T. and Salanterä, S. (2013) Crucial Information Needs of ICU Charge Nurses in Finland and Greece. British Association of Critical Care Nurses, 18, 142-153. https://doi.org/10.1111/nicc.12004

[37] Akerjordet, K. and Severinsson, E. (2010) The State of the Science of Emotional In- 
telligence Related to Nursing Leadership: An Integrative Review. Journal of Nursing Management, 18, 363-382. https://doi.org/10.1111/j.1365-2834.2010.01087.x

[38] Sherman, R.O., Bishop, M., Eggenberger, T. and Karden, R. (2007) Development of a Leadership Competency Model. JONA, The Journal of Nursing Administration, 37, 85-94. https://doi.org/10.1097/00005110-200702000-00011

[39] Kim, M. and Windsor, C. (2015) Resilience and Work-Life Balance in First-Line Nurse Manager. Asian Nursing Research, 9, 21-27. https://doi.org/10.1016/j.anr.2014.09.003

[40] White, K.R., Pillay, R. and Huang, X. (2016) Nurse Leaders and the Innovation Competence Gap. Nurse Outlook, 64, 255-261. https://doi.org/10.1016/j.outlook.2015.12.007

[41] Luo, W.-Y., Shen, N.-P., Lou, J.-H., He, P.-P. and Sun, J.-W. (2016) Exploring Competencies: A Qualitative Study of Chinese Nurse Managers. Journal of Nursing Management, 24, E87-E94. https://doi.org/10.1111/jonm.12295

[42] Sherman, R.O., Saifman, H., Schwartz, R.C. and Schwartz, C.L. (2015) Factors That Lead Generation Y Nurses to Consider or Reject Nurse Leader Roles. NursingPlus Open, 1, 5-10. https://doi.org/10.1016/j.npls.2015.05.001

[43] Doria, H. (2015) Successful Transition from Staff Nurse to Nurse Manager. Nurse Manager, 78-81. https://doi.org/10.1016/j.mnl.2014.07.013

[44] Hendricks, J.M. and Cope, V.C. (2013) Generational Diversity: What Nurse Managers Need to Know. Journal of Advanced Nursing, 69, 717-725. https://doi.org/10.1111/j.1365-2648.2012.06079.x

[45] Ganz, F.D., Wagner, N. and Toren, O. (2015) Nurse Middle Manager Ethical Dilemmas and Moral Distress. Nursing Ethics, 22, 43-51. https://doi.org/10.1177/0969733013515490

[46] Kath, L.M., Stichle, J.F. and Ehrhart, M.G. (2012) Moderators of the Negative Outcomes of Nurse Manager Stress. Journal of Nursing Administration, 42, 215-221. https://doi.org/10.1097/NNA.0b013e31824ccd25

[47] Kath, L.M., Stichler, J.F., Ehrhart, M.G. and Sievers, A. (2013) Predictors of Nurse Manager Stress: A Dominance Analysis of Potential Work Environment Stressors. International Journal of Nursing Studies, 50, 1474-1480. https://doi.org/10.1016/j.ijnurstu.2013.02.011

[48] Labrague, L.J., McEnroe-Petitte, D.M., Leocadio, M.C., Van Bogaert, P. and Cummings, G.G. (2018) Stress and Ways of Coping among Nurse Managers: An Integrative Review. Journal of Clinical Nursing, 27, 1346-1359. https://doi.org/10.1111/jocn.14165

[49] Admi, H. and Moshe-Eilon, Y. (2010) Stress among Charge Nurses: Tool Development and Stress Measurement. Nursing Economics, 28, 151-158.

[50] Brown, P., Fraser, K., Wong, C.A., Muise, M. and Cummings, G. (2013) Factors Influencing Intentions to Stay and Retention of Nurse Managers: A Systematic Review. Journal of Nursing Management, 21, 459-472. https://doi.org/10.1111/j.1365-2834.2012.01352.x

[51] Lee, H. and Cummings, G.G. (2008) Factors Influencing Job Satisfaction of Front Line Nurse Managers: A Systematic Review. Journal of Nursing Management, 16, 768-783. https://doi.org/10.1111/j.1365-2834.2008.00879.x

[52] Bawafaa, E., Wong, C.A. and Laschinger, H. (2015) The Influence of Resonant Leadership on the Structural Empowerment and Job Satisfaction of Registered Nurses. Journal of Research in Nursing, 20, 610-622. 
https://doi.org/10.1177/1744987115603441

[53] Hewko, S.J., Brown, P., Fraser, K.D., Wong, C.A. and Cummings, G.G. (2015) Factors Influencing Nurse Managers' Intent to Stay or Leave: A Quantitative Analysis. Journal of Nursing Management, 23, 1058-1066. https://doi.org/10.1111/jonm.12252

[54] Rudolfsson, G. and Flensner, G. (2012) Suffering and Suffering with the Other-The Perspective of Perioperative Nurse Leaders. Journal of Nursing Management, 20, 278-286. https://doi.org/10.1111/j.1365-2834.2011.01341.x

[55] Shirey, M.R., Mcdaniel, A.M., Ebright, P.R., Fisher, M.L. and Doebbeling, B.N. (2010) Understanding Nurse Manager Stress and Work Complexity: Factors That Make a Difference. Journal of Nursing Administration, 40, 82-91. https://doi.org/10.1097/NNA.0b013e3181cb9f88

[56] Udod, S.A., Cummings, G., Care, W.D. and Jenkins, M. (2017) Impact of Role Stressors on the Health of Nurse Managers. JONA, The Journal of Nursing Administration, 47, 159-164. https://doi.org/10.1097/NNA.0000000000000459

[57] Zwink, J.E., Dzialo, M., Fink, R.M., Oman, K.S., Shiskowsky, K., Waite, K., DeVine, D., Sanders, C.L. and Le-Lazar, J.T.T. (2013) Nurse Manager Perceptions of Role Satisfaction and Retention at an Academic Medical Center. JONA, The Journal of Nursing Administration, 43, 135-141. https://doi.org/10.1097/NNA.0b013e318283dc56

[58] Duffy, E., Avalos, G. and Dowling, M. (2015) Secondary Traumatic Stress among Emergency Nurses: A Cross-Sectional Study. International Emergency Nursing, 23, 53-58. https://doi.org/10.1016/j.ienj.2014.05.001

[59] Matsuzaki, K., Uemura, H. and Yasui, T. (2014) Associations of Menopausal Symptoms with Job-Related Stress Factors in Nurses in Japan. Maturitas, 79, 77-85. https://doi.org/10.1016/j.maturitas.2014.06.007

[60] Warshawsky, N.E. and Havens, D.S. (2014) Nurse Manager Job Satisfaction and Intent to Leave. Nursing Economics, 32, 32-39.

[61] Kath, L.M., Stichler, J.F., Ehrhart, M.G. and Schultze, T.A. (2013) Predictors and Outcomes of Nurse Leader Job Stress Experienced by AWHONN Members. Journal of Obstetric, Gynecologic \& Neonatal Nursing, 42, E12-E25. https://doi.org/10.1111/j.1552-6909.2012.01430.x

[62] Adriaenssens, J., Hamelink, A. and Van Bogaert, P. (2017) Predictors of Occupational Stress and Well-Being in First-Line Nurse Managers: A Cross-Sectional Survey Study. International Journal of Nursing Studies, 73, 85-92. https://doi.org/10.1016/j.ijnurstu.2017.05.007

[63] Heeb, J.L. and Haberey-Knuessi, V. (2014) Health Professionals Facing Burnout: What Do We Know about Nursing Managers? Nursing Research and Practice, 3, 1-7. https://doi.org/10.1155/2014/681814

[64] Van Bogaert, P., Adriaenssens, J., Dilles, T., Martens, D., Van Rompaey, B. and Timmermans, O. (2014) Impact of Role-, Job- and Organizational Characteristics on Nursing Unit Managers' Work Related Stress and Well-Being. Journal of Advanced Nursing, 70, 2622-2633. https://doi.org/10.1111/jan.12449

[65] Wong, C.A. and Laschinger, H.K.S. (2015) The Influence of Frontline Manager Job Strain on Burnout, Commitment and Turnover Intention: A Cross-Sectional Study. International Journal of Nursing Studies, 52, 1824-1833. https://doi.org/10.1016/j.ijnurstu.2015.09.006

[66] Sherman, R.O., Schwarzkopf, R. and Kiger, A.J. (2011) Charge Nurse Perspectives on Frontline Leadership in Acute Care Environments. International Scholarly Re- 
search Network ISRN Nursing, 2011, Article ID: 164052. https://doi.org/10.5402/2011/164052

[67] Lazarus, R.S. and Folkman, S. (1984) Stress, Appraisal, and Coping. Springer, New York.

[68] Karasek, R. and Theorell, T. (1990) Healthy Work: Stress, Productivity, and the Reconstruction of Working Life. Basic Books, New York.

[69] Suzuki, E., Sato, C., Saito, M., Tagaya, A., Mihara, R., Maruyama, A. and Azuma, T. (2009) Relationship between Assertiveness and Burnout among Nurse Managers. Japan Journal of Nursing Science, 6, 71-81. https://doi.org/10.1111/j.1742-7924.2009.00124.x

[70] Hudgins, T.A. (2016) Resilience, Job Satisfaction and Anticipated Turnover in Nurse Leaders. Journal of Nursing Management, 24, E62-E69. https://doi.org/10.1111/jonm.12289

[71] Harris, J.L., Tornabeni, J. and Walters, S.E. (2006) The Clinical Nurse Leader a Valued Member of the Healthcare Team. JONA, The Journal of Nursing Administration, 36, 446-449. https://doi.org/10.1097/00005110-200610000-00003

[72] Brown, A., Dewing, J. and Crookes, P. (2016) Clinical Leadership and Pre-Registration Nursing Programs: A Model for Clinical Leadership and a Prospective Curriculum Implementation and Evaluation Research Strategy. Nurse Education Today, 42, 30-34. https://doi.org/10.1016/j.nedt.2016.03.027

[73] Cathcart, E.B., Greenspan, M. and Quin, M. (2010) The Making of a Nurse Manager: The Role of Experiential Learning in Leadership Development. Journal of Nursing Management, 18, 440-447. https://doi.org/10.1111/j.1365-2834.2010.01082.x

[74] Rankin, J., McGuire, C., Matthews, L., Russell, M. and Ray, D. (2015) Supporting Nursing Leadership by the Implementation of an Increased Supervisory Role GSTF. Journal of Nursing and Health Care, 3, 118-123.

[75] Gonnelli, C. and Raffagnino, R. (2017) Work-Family Conflict in Nursing: An Integrative Review of Its Antecedents and Outcomes. IAFOR Journal of Psychology \& the Behavioral Sciences, 3, 61-84. https://doi.org/10.22492/ijpbs.3.1.05

[76] Nejati, A., Shepley, M., Rodiek, S., Lee, C. and Varni, J. (2016) Restorative Design Features for Hospital Staff Break Areas: A Multi-Method Study. Health Environments Research \& Design Journal, 9, 16-35. https://doi.org/10.1177/1937586715592632 